\title{
Evaluation methodologies of damage related issues for heat exchangers in the thermal storage energy system
}

\author{
Otmane Aboulhassane ${ }^{1, *}$, Abdelhadi El Hakimi ${ }^{1},{\text { Abderrahim } \text { Chamat }^{2} \text {, and Abdelhamid Touache }}^{1}$ \\ ${ }^{1}$ Mechanical Engineering Department, FST, USMBA, Fes, Morocco \\ ${ }^{2}$ Industrial Engineering Department, FST, USMBA, Fes, Morocco
}

\begin{abstract}
Thermal oil is used as a heat transfer fluid in many thermal solar power systems, while molten salts are used to store thermal energy. The oil absorbs solar energy and transports it to a water-steam cycle via heat exchangers, where it is transformed into electric energy via a turbo-generator or stored in a thermal energy storage device for subsequent transmission to the water-steam cycle. The complexity of these thermal solar plants is rather significant, as they mix conventional engineering used in power stations (water-steam cycle) or petrochemical (oil pipeline) with modern solar (parabolic trough collector) and heat storage (molten salts) technology. This paper focuses on modelling in heat exchanger tubes in molten salt energy storage systems, and it offers a comprehensive model of the process. By developing such a model, the groundwork for future study into heat exchangers model failure analysis is established.
\end{abstract}

\section{Introduction}

The heat exchanger in concentrated solar power (CSP) facilities has developed into one of the most developed and researched technologies in the world. However, because of their reliance on sunlight, there is a lack of consistency in the generation of energy [1]. The integration of heat exchangers thermal energy storage (TES) technology in concentrated solar power plants solves this disadvantage, allowing the capacity factor and dispatch ability of concentrated solar power facilities to be increased [2]. reviewed the high temperature of heat exchangers in thermal energy storage concepts in CSP plants [3,4]. They categorized storage methods as active (mostly two-tank and thermocline) or passive (primarily concrete and cast able ceramics) and outlined the key features of each [5]. examined and categorized all concentrated solar power CSP plants globally that employed thermal energy storage TES systems in heat exchangers [ $\neg 6]$. Later, an updated review was performed [7]. They demonstrated that parabolic through is now the most widely used heat exchangers tube in CSP technology, with 80 percent of CSP facilities in service or under development using it [8]. Furthermore, the indirect two-tank molten salt thermal energy storage TES system is the most common TES technology used in this type of concentrated solar power CSP facility [9]. This comprises of two storage tanks (cold and hot) filled with molten salt in which the energy is stored in a perceptible form [10]. A heat transfer fluid (HTF), usually thermal oil, from the parabolic trough solar field, heats the molten salt from the cold storage tank in a heat exchanger. The heated molten salts are then kept in a hot storage tank. When the stored energy is required, the system reverses its operation to heat the heat transfer fluid HTF (Figure 1). The two-tank molten salts system has been theoretically investigated by detailing the best practices during design, start up, and operation in technology projects facilities [11] These studies demonstrated the value and use of constructing pilot plant facilities in a scale range between the laboratory and ultimate CSP plants in order to obtain greater cost reductions in actual CSP plants. They found that a 12-hour storage system at full load capacity decreased the levelled power cost by around $10 \%$ [12]. In the pilot plant facility examined experimentally the molten salts temperature distribution and heat losses. The findings revealed that there was no temperature categorization in the storage tank, and that the radial heat transfer was primarily caused by the insulating material, the type of electrical resistance used for molten salts temperature regulation, the perspective of the storage tanks, and the operating conditions [1315]. The objective of this present paper is to analysing the degradation of the materials of heat exchanger in thermal storage energy systems in the charging and discharging process using molten salt. First, a theoretical study of both heat transfer fluid HTF is done by describing the impact of each thermo-mechanical physical property in the different operational parameters of heat exchanger in CSP plants. Second, experimental research is conducted in which the thermal performance of both HTF in a heat exchanger is compared under various charging procedures.

The authors utilized a two-tank molten salt pilot plant to conduct the experiment [18].

\footnotetext{
* Corresponding author: otmane.aboulhassane@usmba.ac.ma
} 


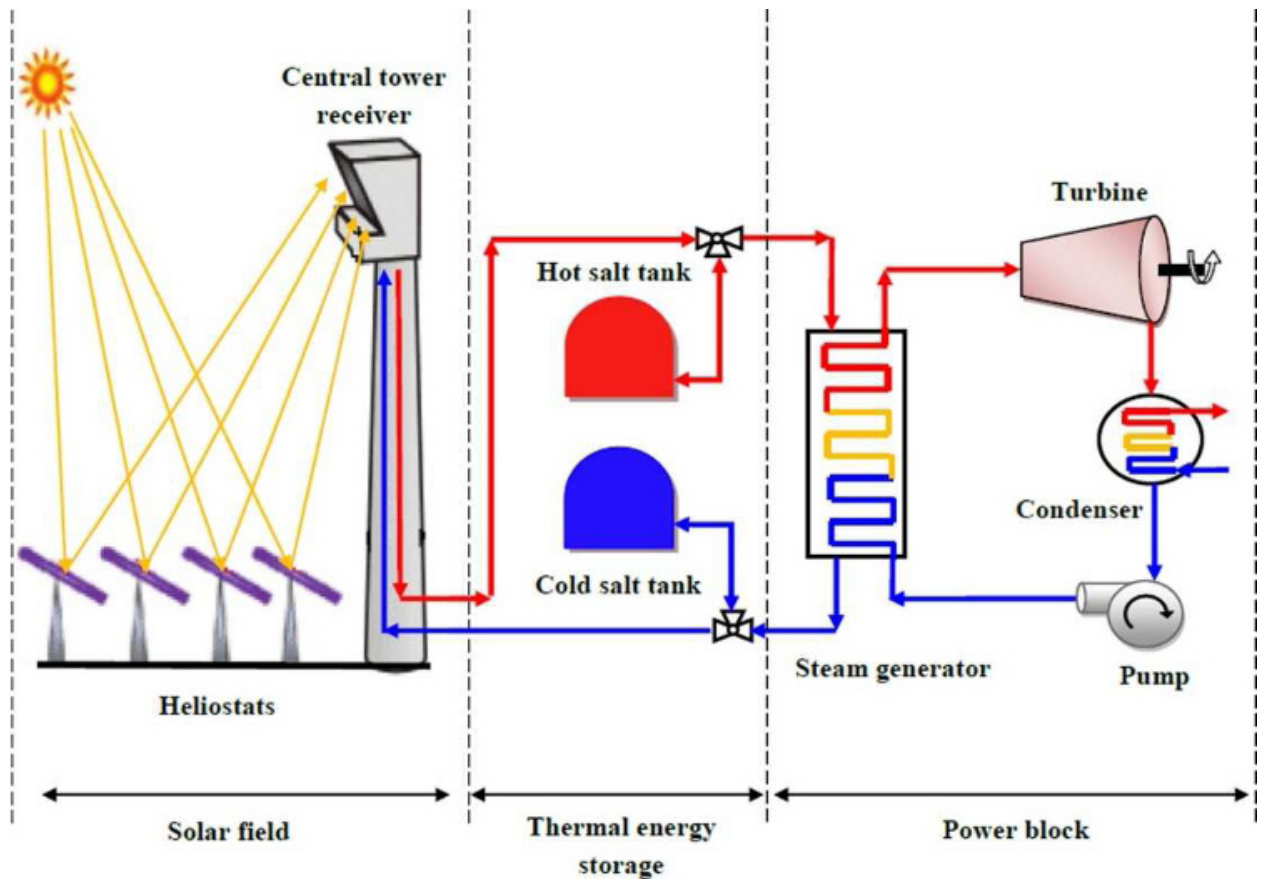

Fig. 1. Scheme of heat exchanger in a concentrated solar power (CES) parabolic an integrated two-tank molten salts (TES) system is shown in this diagram [14]

\section{Materials}

\subsection{Heat transfer fluid in TES system}

Molten salt is the binary eutectic combination of 60 weight percent sodium nitrate and 40 weight percent potassium nitrate, commonly known as molten salt or sun salt, was chosen as the TES material. This material is widely utilized for TES, mostly in CSP plants, and its thermos-mechanical physical characteristics have been investigated and reviewed thoroughly in earlier research works [19,20].

A heat exchanger functions as a cooling system. The storage system comprises two $0.57 \mathrm{~m} 3$ molten salt storage tanks with the same aspect ratio as real CSP storage tanks. During the charging and discharging operations, they contain $1000 \mathrm{~kg}$ of molten salts, which are stored and recirculated through the molten salts loop.

In addition, the authors of this work examined and characterized the most important characteristics of molten salts in the degradation of heat exchangers tubes, which are listed in Table 1.

\subsection{Heat exchanger}

Thermal exchangers are used to transferring heat between two fluids effectively, with or without the need for a complete wall separation. Evaporation, condensation, or even a phase shift can be used to transfer heat between two fluids.

When a temperature differential develops, energy is transmitted in the form of heat, which might be responsive or latent.
Table 1. Thermo-physical characteristics of molten salts in thermal energy storage TES system [12]

\begin{tabular}{|c|c|}
\hline Properties & Values \\
\hline Composition & $\begin{array}{c}\mathrm{NaNO}_{2} / \\
\mathrm{KNO}_{2},(60 / 40 \\
\text { wt, \%) }\end{array}$ \\
\hline Aspect & $\begin{array}{l}\text { White in solid } \\
\text { and } \\
\text { transparent } \\
\text { yellow in fluid } \\
\text { crystalline }\end{array}$ \\
\hline $\begin{array}{c}\text { Melting } \\
\text { point }\end{array}$ & $238.241^{\circ} \mathrm{C}$ \\
\hline Density & $\begin{array}{c}\rho\left(\mathrm{kg} / \mathrm{m}^{3}\right)= \\
0.636 \mathrm{~T}\left({ }^{\circ} \mathrm{C}\right)+ \\
2089.905\end{array}$ \\
\hline Specific heat & $\begin{array}{c}\mathrm{Cp}(K j / k g . K)= \\
1.723 . \mathrm{E}- \\
4 . \mathrm{T}\left({ }^{\circ} \mathrm{C}\right)+ \\
1.443 \\
\end{array}$ \\
\hline $\begin{array}{c}\text { Thermal } \\
\text { conductivity }\end{array}$ & $\begin{array}{c}\lambda(\mathrm{W} / \mathrm{m} \cdot \mathrm{K})= \\
1.9 \mathrm{E}-4\left({ }^{\circ} \mathrm{C}\right)+ \\
0.443\end{array}$ \\
\hline $\begin{array}{l}\text { Kinematic } \\
\text { viscosoty }\end{array}$ & $\begin{array}{c}v\left(\mathrm{~m}^{2} / \mathrm{s}\right)=- \\
6.557 . \mathrm{E}-14 \\
\mathrm{~T}^{3}\left({ }^{\circ} \mathrm{C}\right)+ \\
1.055 \mathrm{~T}^{2}\left({ }^{\circ} \mathrm{C}\right)- \\
5.706 \mathrm{~T}\left({ }^{\circ} \mathrm{C}\right)+ \\
1.112 . \mathrm{E}-5\end{array}$ \\
\hline
\end{tabular}

The most prevalent type of thermal tube exchanger is seen in solar power plants [17]. A shell, cylinders, chicanes, and tubular plates are the main components of heat exchangers. 


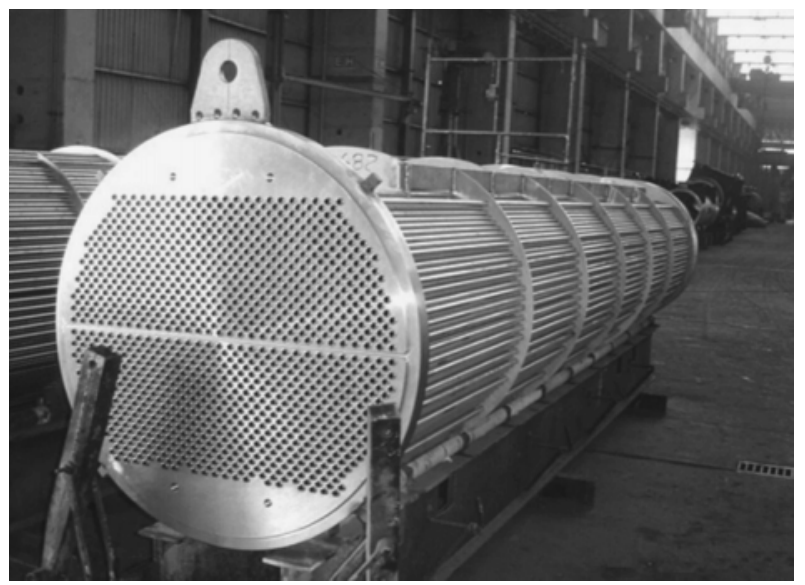

Fig. 2. Heat Exchangers model for case study [16]

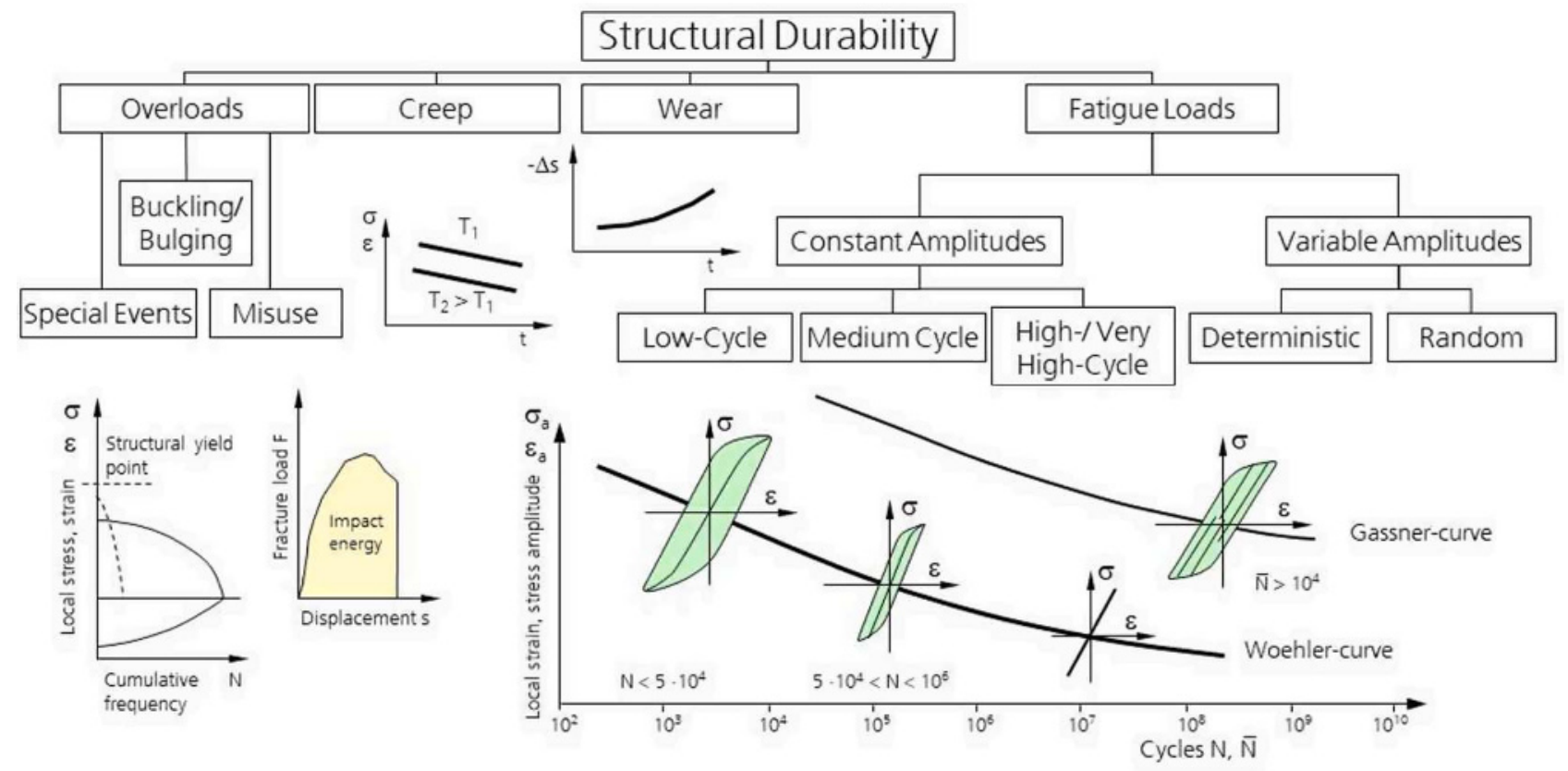

Fig. 3. Description of the structural failure [11]

The tube's base is responsible for transferring fluid heat from the sale side to the tube's interior and vice versa. When in operation or in an inoperable condition, the tube's material and design must be resistant to overheating, sowing irregularities, thermomechanical fatigue, corrosion, and oxygen damage. We employ optimal working conditions, efficient design, and environmental resilience to avoid system failures. Fig. 2 illustrate a tubular heat exchanger research model.

\section{Damage}

\subsection{Fatigue damage}

Corrosion fatigue is caused by the simultaneous action of a corrosive environment and cyclic loads. The heat exchanger is subjected to a constant load in the form of thermal and mechanical strains, resulting in tube failure due to cracking. Corrosion fatigue occurs when metals are subjected to dynamic stresses in any corrosive environment, whereas stress corrosion cracking occurs when metals are subjected to static stressors. Corrosion fatigue occurs in metals when dynamic stresses operate on them in any corrosive environment, whereas stress corrosion cracking occurs when static stressors act on them in a particular chemical environment. Corrosive environment materials are also prone to corrosion fatigue. Thermal overloading and mechanical overstressing are the two major causes of fatigue [1820]. High temperature is the cause of failure in the first scenario, while high mechanical stresses are the reason for failure in the second situation.

Residual stresses are created in materials during bending and rolling when mechanical stresses are large, although they may be reduced by post-weld heat treatment. Fatigue may also be caused by microstructure change and porosity. Thermal fatigue is damaging to heat exchangers and can lead to failure fast [21].

The failure of bayonet type boiler tubes working in the molten salt, and nitrogen-rich atmosphere was examined. 


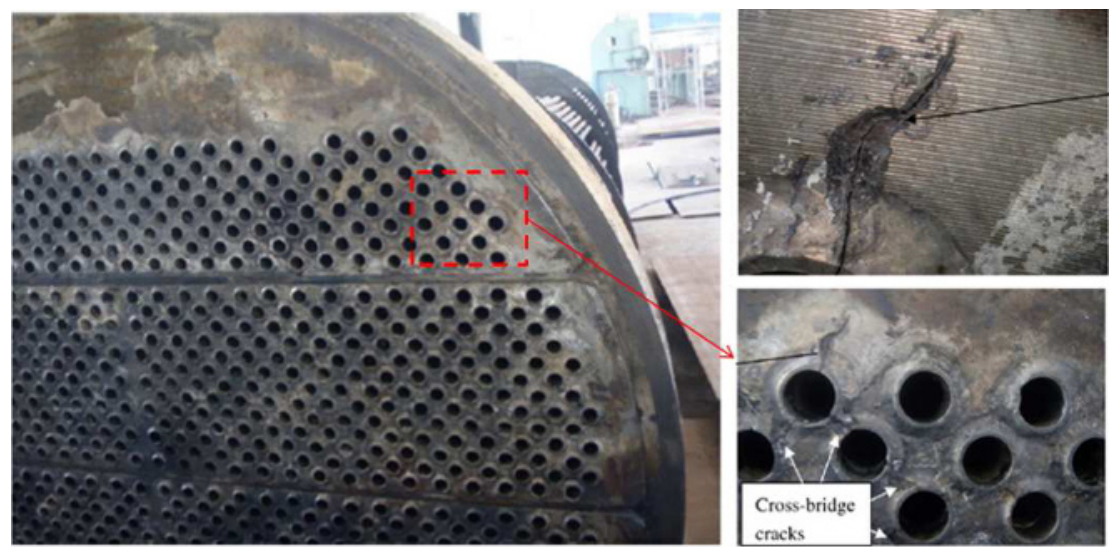

Fig. 4. Circumferential cracks and bulged region in tube sheet of heat exchanger [19]

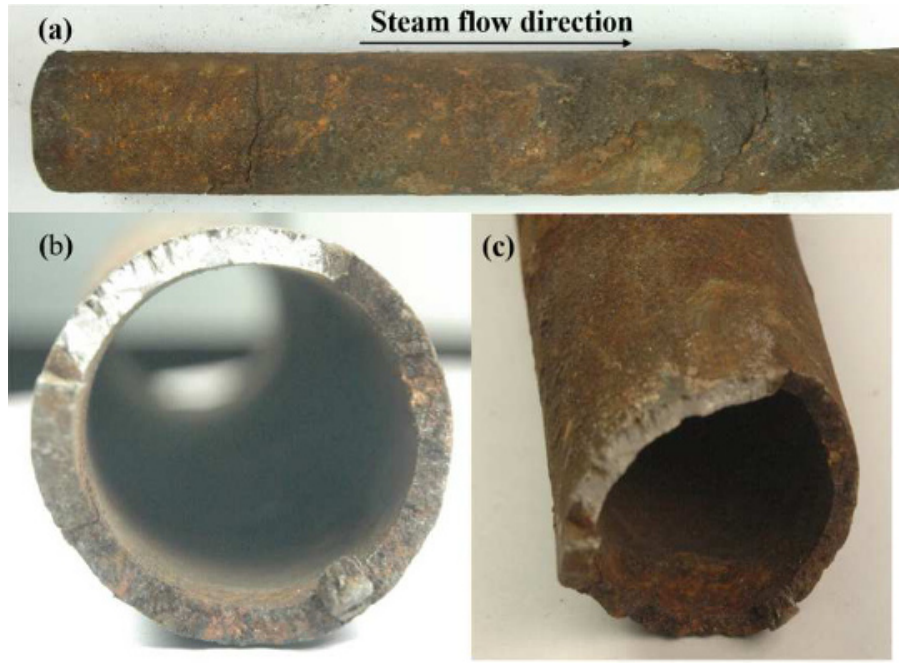

Fig. 5. Circumferential cracks and bulged steam flow direction in the tube of heat exchanger [22]

In the TES system, the tubes constructed of $316 \mathrm{~L}$ stainless steel worked in a medium including water inside the tubes and process gas on the shell side. As seen in Fig. 4.

In the heat exchanger, the process gas was utilized at $360^{\circ} \mathrm{C}$, while steam was produced at $306^{\circ} \mathrm{C}$ and 15 bar pressure. Thermal fatigue was discovered to be the underlying cause of tube failure, which was caused by temperature fluctuation due to inadequate water circulation. Thermal strains resulted in fatigue, which was then followed by water leakage. Circumferential cracks across the tube axis were discovered during the investigation, demonstrating thermal fatigue failure of tubes, thermal fatigue, and corrosion fatigue reduce the service life of heat exchangers [16] as illustrated in Fig. 4, and Fig. 5.

\subsection{Oxidation damage}

Due to material affinity, high temperature, and an oxidizing atmosphere, heat exchangers are prone to oxidation. The failure of L304 stainless steel tubes in a flue gas medium including alumina and silica particles was examined [22]. The oxide layer that had developed around a hole in the tube surface had fractured.
According to the stereoscopic study of the failure region, as presented in Fig. 6. Steel's strong propensity for reacting with oxygen resulted in the formation of this layer at the tube's surface. At high temperatures and in oxidizing conditions, oxidation kinetics is quite fast. The tube's exterior wall oxidized after being exposed to a hostile environment. At the interior side of the tube, water or steam created adherent oxide layers, thus no oxidation was detected. Super-heater boiler tubes constructed of L316 stainless steel functioning in a water medium with 92 bar pressure were examined in a concentrated solar power CSP of thermal energy storage TES. The collapse of boiler tubes was established as a result of localized overheating induced by molten salt heat flux assault. Steam quickly developed in the tubes due to overheating, causing steam blanketing, and the temperature of the tubes was elevated to $700{ }^{\circ} \mathrm{C}$.

Overheating caused an oxide layer to develop on the interior surface of the tubes, according to the physical structure study. Magnetite was recognized as the oxide (Fe3O4). The thickness of the oxide in the heated zone around the crack region of the afflicted tubes was 0.44 $\mathrm{mm}$. The microstructure of the tube at the fracture site was affected by the increase in temperature, as illustrated in Fig. 6. where a ferrite matrix containing carbide particles can be seen. 

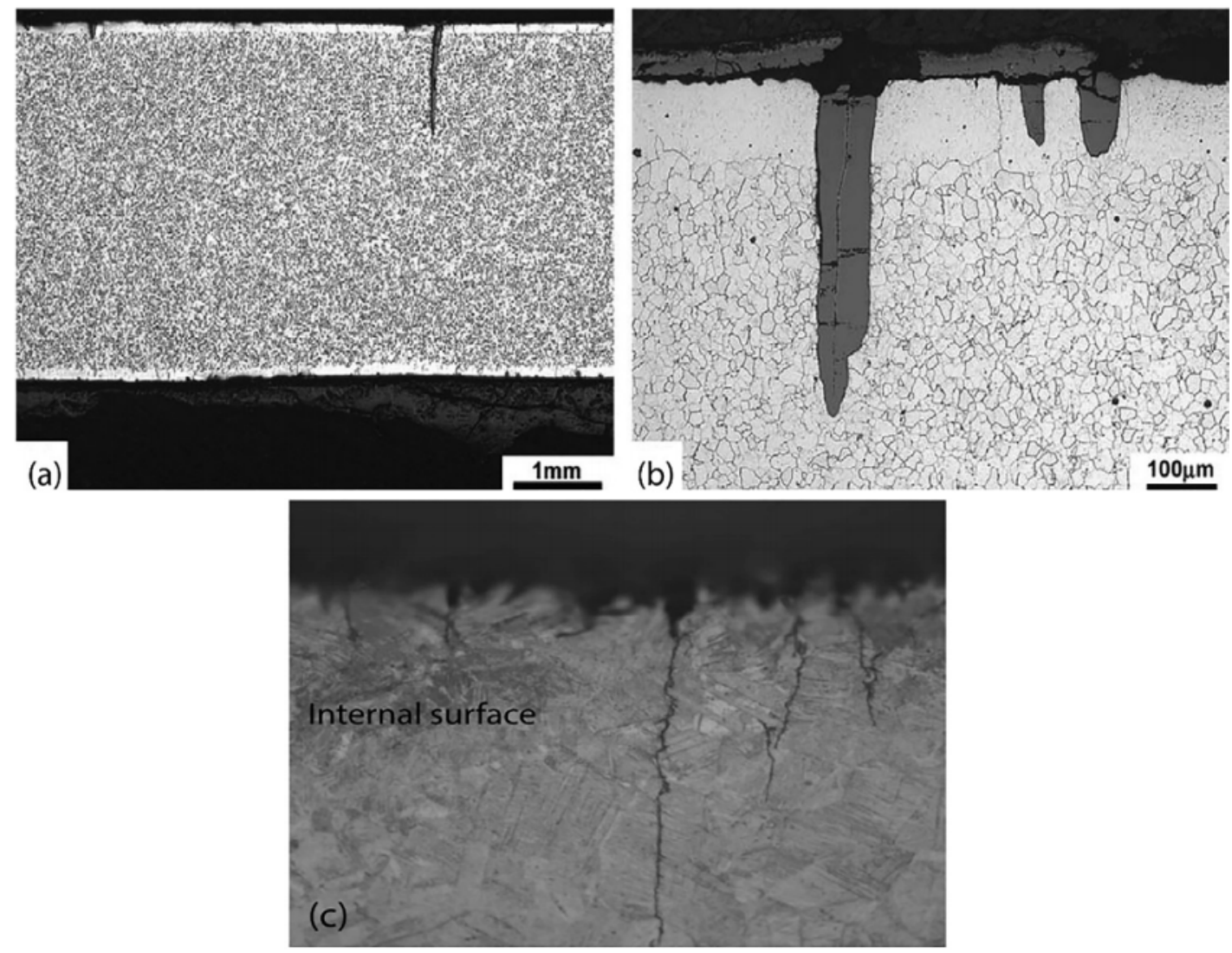

Fig. 6. Microscopic image of cracks at internal surface of the tube (a), (b) and (c) exchanger [23]

\subsection{Creep damage}

Boiler water tubes, super-heater tubes, and reformer tubes are all important parts of heat exchangers. Creep occurs when these components are exposed to an aggressive environment, causing them to become more stressed over time. Time, temperature, and stress are the major variables that affect the rate of deformation, which finally leads to component creep rupture. Tubes that are exposed to creep-prone working conditions have a lower lifetime. Creep rupture is responsible for around $30 \%$ of all heat exchanger component failures. Intergranular, trans-granular, or rupture failures can occur as a result of creep deterioration in the affected areas [23].

The creep rupture failure of a $2.25 \mathrm{Cr} 1 \mathrm{Mo}$ steeliness, molten salt boiler tube was investigated. The cooling action in the system was limited by an oxide layer $(0.25$ $\mathrm{mm}$ thick), resulting in a rise in tube temperature. The combined action of the oxide layer and the flue gas utilized at $920{ }^{\circ} \mathrm{C}$ caused the temperature to rise. There was evidence of inter-granular ferrite, trans-granular ferrite, and inter-granular austenite development, which finally led to creep rupture. At the broken tube's edge, martensitic production was detected. Increased temperature exacerbated thinning, resulting in a reduction in tube thickness, illustrating the fracture mechanism.

After 16 years of operation, the shell of a heat exchanger built of a heat-resistant alloy failed [22]. Creep failure was discovered in the shell's weld joints after a thorough investigation.
This is due to the shell being subjected to superheated steam at $720^{\circ} \mathrm{C}$, which caused creep micro voids and fractures. The chemical composition of the weld joints was discovered to be different from what was needed. To avoid such failure, timely examination of the heat exchanger base and weld materials for longterm creep exposure is required [23-25].

\subsection{Weld damage}

From the weld metal to the heat-affected zone to the unaffected base metal, the welding connection produces an inhomogeneous microstructure. Welding can also cause roughness, voids, porosity, inclusions, discontinuities, and shrinkage fractures [21].

Adherence to correct welding procedures is essential for generating a homogenous weld structure that results in enhanced and long-term heat exchanger performance. Failure can be caused by poor base and weld metal selection, heat treatment, and the presence of mechanical loads. Weld joints in heat exchangers are less resistant to cyclic stress and misalignment [17].

Due to fatigue fracture, a brazed joint in a 304 stainless steel heat exchanger leaked. It was deduced via macroscopic inspection, metallographic examination, spectral analysis, and finite element analysis that a fracture developed at the flange of a brazing joint owing to fatigue, which finally led to the heat exchanger's failure. 
Table 2. Review of heat exchangers damage

\begin{tabular}{|c|c|c|c|c|c|c|c|}
\hline $\mathrm{S} / \mathrm{N}$ & Heat exchanger & Material & Damage mechanism & $\begin{array}{l}\text { Damage } \\
\text { mode }\end{array}$ & $\begin{array}{l}\text { Causes of } \\
\text { damage }\end{array}$ & Preventive measures & Ref. \\
\hline 1 & $\begin{array}{lr}\text { Tube } & \text { sheet to } \\
\text { tube } & \text { welded } \\
\text { joint } & \end{array}$ & $\begin{array}{l}\text { ASTM } \\
\text { B127 } \\
\text { grade } 400\end{array}$ & $\begin{array}{l}\text { Fatigue Analysis in a } \\
\text { Bellow Expansion Joint } \\
\text { Installed a Heat } \\
\text { Exchanger }\end{array}$ & $\begin{array}{l}\text { Thermo- } \\
\text { mechanical } \\
\text { Fatigue }\end{array}$ & $\begin{array}{l}\text { Insufficient } \\
\text { Materials } \\
\text { selection }\end{array}$ & $\begin{array}{l}\text { Admiralty brass for } \\
\text { proper cooling water } \\
\text { management. It's also } \\
\text { a good idea to use Al- } \\
\text { brass or cupper-nickel } \\
\text { alloys. }\end{array}$ & [17] \\
\hline 2 & $\begin{array}{l}\text { Outer surface of } \\
\text { heat exchanger } \\
\text { tubes serpentine }\end{array}$ & $\begin{array}{l}\text { ASTM A } \\
\text { 178, L304 } \\
\text { stainless } \\
\text { steel }\end{array}$ & $\begin{array}{l}\text { Fracture in weld joint, } \\
\text { fatigue fracture, and } \\
\text { thermal } \\
\text { cracking }\end{array}$ & $\begin{array}{l}\text { Corrosion } \\
\text { fatigue }\end{array}$ & $\begin{array}{l}\text { Thermal } \\
\text { cycling }\end{array}$ & $\begin{array}{l}\text { Control corrosion } \\
\text { products formation } \\
\text { and optimize the } \\
\text { operation of the heat } \\
\text { exchangers. }\end{array}$ & [18] \\
\hline 3 & $\begin{array}{l}\text { Heat exchanger } \\
\text { tubes }\end{array}$ & $\begin{array}{l}\text { ASTM } \\
215 \text { grade } \\
200\end{array}$ & $\begin{array}{l}\text { Thermal cycling- } \\
\text { localized over heating } \\
\text { bulging-thermal fatigue } \\
\text { cracking }\end{array}$ & $\begin{array}{l}\text { Thermo- } \\
\text { mechanical } \\
\text { fatigue }\end{array}$ & $\begin{array}{l}\text { Thermal } \\
\text { cycling is } \\
\text { caused by } \\
\text { poor water } \\
\text { circulation. }\end{array}$ & $\begin{array}{l}\text { Maintain ideal } \\
\text { working conditions. }\end{array}$ & [19] \\
\hline 4 & $\begin{array}{l}\text { Super heater } \\
\text { tubes }\end{array}$ & $\begin{array}{l}15 \mathrm{MoCr} \\
\text { Carbon } \\
\text { steel }\end{array}$ & $\begin{array}{l}\text { Overheating creates } \\
\text { creep fatigue. }\end{array}$ & Creep fatigue & $\begin{array}{l}\text { oxide layer } \\
\text { formation }\end{array}$ & $\begin{array}{l}\text { Material that is more } \\
\text { heat resistant. }\end{array}$ & [20] \\
\hline 5 & $\begin{array}{l}\text { Weld inside the } \\
\text { shell }\end{array}$ & $80 \mathrm{H}$ steel & $\begin{array}{l}\text { Overheating creates } \\
\text { fracture of creep fatigue }\end{array}$ & Creep fatigue & $\begin{array}{l}\text { Steam } \\
\text { exposure at a } \\
\text { high } \\
\text { temperature }\end{array}$ & $\begin{array}{l}\text { Metals in the base and } \\
\text { welds are inspected. }\end{array}$ & [21] \\
\hline 6 & $\begin{array}{lr}\text { Super } & \text { heater } \\
\text { tube } & \text { in } \\
\text { combustor } & \end{array}$ & $\begin{array}{l}\text { Carbon } \\
\text { steel }\end{array}$ & $\begin{array}{l}\text { High } \\
\text { oxidation }\end{array}$ & Oxidation & $\begin{array}{l}\text { High velocity } \\
\text { of } \mathrm{AL}_{2} \mathrm{O}_{2} \text { in } \\
\text { fluid } \\
\text { transported } \\
\text { of the } \\
\text { exchangers }\end{array}$ & $\begin{array}{l}\text { Optimize the process } \\
\text { and lower the } \\
\text { maximum } \\
\text { temperature. }\end{array}$ & [22] \\
\hline 7 & $\begin{array}{l}\text { Nozzle of high } \\
\text { pressure }\end{array}$ & SA169 & Fracture do to cracking & $\begin{array}{l}\text { Fatigue } \\
\text { fracture }\end{array}$ & $\begin{array}{l}\text { Repetitive } \\
\text { load is } \\
\text { present }\end{array}$ & $\begin{array}{l}\text { Use an adjoins nozzle } \\
\text { to replace the threads } \\
\text { nozzle. }\end{array}$ & [23] \\
\hline 8 & $\begin{array}{l}\text { Brazing joint in } \\
\text { heat exchangers } \\
\text { tubes }\end{array}$ & $\begin{array}{l}\text { Stainless } \\
\text { steel }\end{array}$ & Stress concentration & $\begin{array}{l}\text { Fatigue } \\
\text { fracture }\end{array}$ & $\begin{array}{l}\text { Presence of } \\
\text { repetitive } \\
\text { load and } \\
\text { stress }\end{array}$ & $\begin{array}{l}\text { Avoid components } \\
\text { with non-parallel } \\
\text { gaps and significant } \\
\text { shear stresses. }\end{array}$ & [24] \\
\hline 9 & $\begin{array}{l}\text { In a hydro- } \\
\text { treated, a heat } \\
\text { exchanger tube } \\
\text { is used }\end{array}$ & $\begin{array}{l}\text { Carbon } \\
\text { steel }\end{array}$ & $\begin{array}{l}\text { Corrosion at high } \\
\text { temperatures }\end{array}$ & $\begin{array}{l}\text { Corrosion } \\
\text { fatigue }\end{array}$ & $\begin{array}{l}\text { The presence } \\
\text { of } \mathrm{H}_{2} \text { at } \\
\text { temperatures } \\
\text { over } 205^{\circ} \mathrm{C}\end{array}$ & $\begin{array}{l}\text { In such cases, a high } \\
\text { applied load or } \\
\text { residual stresses are } \\
\text { advantageous. }\end{array}$ & {$[25]$} \\
\hline 10 & $\begin{array}{l}\text { Tubes for } \\
\text { transferring line }\end{array}$ & $\begin{array}{l}\text { N08810 } \\
\text { alloy }\end{array}$ & $\begin{array}{l}\text { Carburization at high } \\
\text { temperatures }\end{array}$ & Carburization & $\begin{array}{l}\text { Carbide } \\
\text { phase } \\
\text { precipitation }\end{array}$ & Alloy to be replaced. & [26] \\
\hline
\end{tabular}

\subsection{Vibration damage}

The oscillation of tubes about their equilibrium point can lead to resonance and cause mechanical failure. Vibration creates fractures which spread via the component. The vibration also leads to material loss and damage equipment by fretting corrosion due to either tube-to-tube support contact or fatigue [27]. Vibration occurs between elements of heat exchangers; such as baffles or tube sheets. Vibration failure is caused by two factors: the heat exchanger's surroundings and flow conditions such as turbulent flow. When two or more surfaces come into contact under severe circumstances, such as the cyclic relative motion of two surfaces in the presence of load-induced vibration, fretting corrosion develops. Friction between surfaces damages the passive film as they come into contact in relative motion, exposing metal surfaces to the corrosive environment.

\section{Conclusion}

Heat exchangers are used in a variety of industries, including chemical, petrochemical, electric, and nuclear power plants, as well as refrigeration, gas processing, and sewage treatment units. Heat exchanger failure leads to a loss of production and capital. Catastrophic failure can result in serious harm or death. Fatigue, creep, corrosion, oxidation, and hydrogen attack are the most prevalent failure mechanisms. Fouling, scaling, salt deposition, weld flaws, and vibrations are some of the factors that lead to failure. The most common failure modes found in this research were creep and fatigue. 
Any strategy for extending a heat exchanger's service life and increasing its cost-effectiveness should consider a number of factors, including essential workforce training, material selection, exchanger design, and strict control of operating conditions like fluid chemistry, $\mathrm{pH}$, velocity, temperature, pressure, and vibration level.

\section{Appendix. damage constitutive equations- Elasto viscoplastic laws}

The purpose of this appendix is to describe the technique for obtaining the fatigue damage constitutive equations from the elasto-viscoplastic laws and evolution laws. A very simple problem is studied in order to better understand the properties of the model and the role of the thermomechanical couplings [24].

$$
\begin{aligned}
& =\left(\begin{array}{ll}
1 & D
\end{array}\right)\left[\frac{E}{2(1+)}(=\stackrel{p}{=})\right. \\
& \left.+\frac{}{(1} 2\right) \cdot \operatorname{tr}(=\stackrel{p}{=}] \\
& \underline{\underline{p}}=(3 / 2)(f / k)^{n} \frac{\left(\underline{\underline{\underline{B^{c}}}}\right)_{d e v}}{J\left(\underline{\underline{B^{c}}}\right)} \\
& \underline{\underline{B^{c^{i}}}}=(1 \quad D)\left[a_{i} \underline{\underline{c^{i}}}\right](i=1,2,3) \\
& \underline{\underline{c}}^{i}=\underline{\underline{p}}+\left({ }_{i} / a_{i}\right)\left(\underline{\underline{B}}^{c^{i}} p\right)(i=1,2,3) \\
& \underline{\underline{p}}=(f / k)^{n}=\left[(2 / 3)\left(\underline{\underline{p}}:{ }^{p}\right)\right]^{1 / 2} \\
& D=\left(B^{D} / S_{0}\right) p \\
& D=f\left(D_{\text {fatigue }}, D_{\text {creep }}, D_{\text {oxydation }}, D_{\text {vibration }}\right) \\
& D_{\text {tot }}=D_{\text {fatigue }}+D_{\text {creep }}+D_{\text {oxydation }}+D_{\text {vibratio }}
\end{aligned}
$$

Where, Dfatigue, Dcreep, Doxidation and Dvibration are accumulated fatigue damage, creep damage, oxidation damage and vibration damage respectively. $D$ is the criteria value for total damage. $N_{f}$ is fatigue life, $t_{r}$ is time to rupture, $\Delta \varepsilon t$ is strain range, $T$ is temperature and $\sigma(\mathrm{t})$ is stress at time $t$. Because damage equals $1 / \mathrm{Nf}$, equation (8) may be recast in terms of the failure life, Nf.

$$
\frac{1}{N_{f}}=\frac{1}{N_{f}^{f a t}}+\frac{1}{N_{f}^{\text {creep }}}+\frac{1}{N_{f}^{\text {oxid }}}+\frac{1}{N_{f}^{\text {vibra }}}
$$

The following is an explanation of these damage terminology. The strain-life equation [27] represents the fatigue damage term, which is examined in the following article investigation.

\section{References}

1. M.J. Li, W.Q. Tao, Review of methodologies and polices for evaluation of energy efficiency in high energy-consuming industry, Appl. Energy 187 (2017) 203-215

2. Z. Ma, W.W. Yang, F. Yuan, B. Jin, Y.L. He, Investigation on the thermal performance of a hightemperature latent heat storage system, Appl. Therm. Eng. 122 (2017) 579-592.

3. K.B. Tokarska, N.P. Gillett, Cumulative carbon emissions budgets consistent with $1.5 \mathrm{C}$ global warming, Nat. Clim. Change 8 (2018) 296.

4. Y.L. He, K. Wang, Y. Qiu, B.C. Du, Q. Liang, S. $\mathrm{Du}$, Review of the solar flux distribution in concentrated solar power: non-uniform features, challenges, and solutions, Appl. Therm. Eng. 149 (2019) 448-474.

5. M.J. Li, Y.L. He, W.Q. Tao, modeling a hybrid methodology for evaluating and forecasting regional energy efficiency in China, Appl. Energy 185 (2017) 1769-1777.

6. K. Wang, Y.L. He, Thermodynamic analysis and optimization of a molten salt solar power tower integrated with a recompression supercritical $\mathrm{CO} 2$ Brayton cycle based on integrated modeling, Energy Convers. Manage. 135 (2017) 336-350.

7. M.J. Li, B. Jin, Z. Ma, F. Yuan, Experimental and numerical study on the performance of a new hightemperature packed-bed thermal energy storage system with macro encapsulation of molten salt phase change material, Appl. Energy 221 (2018) 115

8. M.J. Li, B. Jin, J.J. Yan, Z. Ma, M.J. Li, Numerical and experimental study on the performance of a new two-layered high-temperature packed-bed thermal energy storage system with changeddiameter macro encapsulation capsule, Appl. Therm. Eng. 142 (2018) 830-845.

9. Z. Ma, M.J. Li, W.W. Yang, Y.L. He, General performance evaluation charts and effectiveness correlations for the design of thermocline heat storage system, Chem. Eng. Sci. 185 (2018) 105115.

10. Y. Qiu, M.J. Li, W.Q. Wang, B.C. Du, K. Wang, an experimental study on the heat transfer performance of a prototype molten-salt rod baffle heat exchanger for concentrated solar power, Energy 156 (2018) 63-72

11. Y.L. He, Z.J. Zheng, B.C. Du, K. Wang, Y. Qiu, Experimental investigation on turbulent heat transfer characteristics of molten salt in a shell-andtube heat exchanger, Appl. Therm. Eng. 108 (2016) 1206-1213

12. B. Vriesema, Aspects of Molten Fluorides as Heat Transfer Agents for Power Generation [PhD], Delft University of Technology, Delft, Netherlands, 1979. 
13. Y.T. Wu, C. Chen, B. Liu, C.F. Ma, Investigation on forced convective heat transfer of molten salts in circular tubes, Int. Commun. Heat Mass Transfer 39 (2012) 1550-1555.

14. J. Qian, Q. Kong, H. Zhang, W. Huang, W. Li, Performance of a gas cooled molten salt heat exchanger, Appl. Therm. Eng. 108 (2016) 1429_ 1435.

15. Y.S. Chen, Y. Wang, J.H. Zhang, X.F. Yuan, J. Tian, Z.F. Tang, et al., Convective heat transfer characteristics in the turbulent region of molten salt in concentric tube, Appl. Therm. Eng. 98 (2016) 213-219.

16. B. Liu, Y.T. Wu, C.F. Ma, M. Ye, H. Guo, Turbulent convective heat transfer with molten salt in a circular pipe, Int. Commun. Heat Mass Transfer 36 (2009) 912-916.

17. L.K. Zhu, L.J. Qiao, X.Y. Li, B.Z. Xu, W. Pan, L. Wang, Alex A. Volinsky, Analysis of the tube-sheet cracking in slurry oil steam generators, Eng. Fail. Anal. 34 (2013) 379-386

18. J. Mao, D. Tang, S. Bao, L. Luo, Z. Gao, High temperature strength and multiaxial fatigue life assessment of a tubesheet structure, Eng. Fail. Anal. 68 (2016) 10-21.

19. S. Xu, Y. Zhao, Using FEM to determine the thermo-mechanical stress in tube to tube-sheet joint for the SCC failure analysis, Eng. Fail. Anal. 34 (2013) 24-34

20. W. Gao, Y. Lia, L. Kong, Numerical investigation of erosion of tubesheet and tubes of a shell and tube heat exchanger, Comput. Chem. Eng. 96 (2017) 115-127

21. S. Rongjuan, W. Weiqiang, L. Yan, L. Dong, L. Wei, Root cause analysis of stress corrosion at tubeto-tubesheet joints of a waste heat boiler, Eng. Fail. Anal. 45 (2014) 398-405.

22. R. Patil, S. Anand, Thermo-structural fatigue analysis of shell and tube type heat exchanger, Int. J. Press. Vessel. Pip. 155 (2017) 35-42

23. S. Xu, C. Wang, W. Wang, Failure analysis of stress corrosion cracking in heat exchanger tubes during start-up operation, Eng. Fail. Anal. 51 (2015) 1-8

24. Z. Wang, Q. Shi, Q. Li, L. Wan, H. Tang, Transient thermal stress and temperature change rate analysis of fixed tubesheet, ASME Pressure Vessels and Piping Conference, vol. 3A, 2018.

25. Y. Wang, X. Gu, Z. Jin, K. Wang, Characteristics of heat transfer for tube banks in crossflow and its relation with that in shell-and-tube heat exchangers, Int. J. Heat Mass Transf. 93 (2016) 584-594.

26. J.S. Corte, J.M.A. Rebello, M.C.L. Areiza, S.S.M. Tavares, M.D. Araujo, Failure analysis of AISI 321 tubes of heat exchanger, Eng. Fail. Anal. 56 (2015) 170-176.

27. M. Mellal, R. Benzeguir, D. Sahel, H. Ameur, Hydro-thermal shell-side performance evaluation of a shell and tube heat exchanger under different baffle arrangement and orientation, Int. J. Therm. Sci. 121 (2017) 138-149. 